\title{
The Role of Chinese Excellent Traditional Culture on the Ideological Work of Colleges and Universities
}

\author{
Qiongying $\mathrm{Li}^{1, \mathrm{a}}$ \\ ${ }^{1}$ Environmental College, Wuhan Textile University, Hubei, Wuhan, China, 430200
}

\begin{abstract}
Keywords: Chinese Excellent Traditional Culture; Colleges and Universities; Ideological Security; Cultural Function
\end{abstract}

\begin{abstract}
Chinese excellent traditional culture contains the Chinese nation's fine cultural gene, condensing the deep-rooted spiritual pursuit of the Chinese people. This article starts from exploring the function of excellent Chinese traditional culture, based on the new problems in the ideological work of colleges and universities and this paper analyzes the promotion of Chinese outstanding traditional culture to the ideological work of colleges and universities.
\end{abstract}

\section{Introduction}

Colleges and universities are not only important places for cultural heritage, but also in the ideological field of the complex and fierce frontier positions, under the new situation, do ideological work in colleges and universities, the security and stability of the whole society has important practical significance. With the continuous strengthening of national economic strength, "culture has become an important source of national cohesion and creativity". It is not only historic but also important practical significance. Since the Han Dynasty, the Confucian culture in Chinese traditional culture has become the official thought of the ruling class, and the social primary consciousness has become the main idea of the Chinese traditional culture. Therefore, through the deep value of the concept of excellent culture and its modern significance to be excavated and explained, to explore the traditional Chinese culture of modern survival of the way, for the ideology of colleges and universities as well as the ideology of the community to play their due effect.

\section{The Function of Chinese Outstanding Traditional Culture}

Chinese traditional culture covers a wide range of content, not only contains Confucianism, Taoism, legalists and other conceptual culture, but also includes the tax system, service system, examination system and other institutional culture, including art, architecture, and clothing and other physical culture, In addition, also contains Chinese medicine, astronomical calendar and other related content. It can be seen that Chinese traditional culture is related to all aspects of life, profound impact on each person's daily life, to promote the progress and development of society at that time played an important role, therefore, in the cultural function, from the people ideology Play an important role in the starting point of view, mainly guided function, shaping the function and nurturing functions, these functions in promoting economic development, ease social contradictions and improve people's ideological literacy and so played an important role.

The Ideological-Oriented Function. Chinese fine traditional culture accumulated under the developed moral norms system, deeply into the Chinese nation's ideology and behavior norms, affecting the social life and personal aspects of life. In the relationship between people and people, between husband and wife to respect each other, between the monarch and the minister to talk about loyalty letters, between parents and children to talk about filial piety and morality; in the formation of ideas, "Heaven" pointed out that human society and The harmony of nature, emphasizing the establishment of a harmonious world view, "do not want to do, do not impose on others" contains a wealth of love for others, to treat people's life concept of faith, "wealth cannot prostitution, poor and poor cannot move, this is a man "is stressed that the righteousness of light, the spirit of giving birth to justice, educate young people to establish the correct values. Chinese outstanding traditional culture plays an irreplaceable and important role in unifying people's ideology and playing the 
guiding function of moral value.

The Shaping Function of Moral Qualities. Cultivating noble moral sentiment is the core content of Chinese outstanding traditional culture. Confucius pioneered the Confucian school, with moral education as its theoretical doctrine of the main axis, shaping the Chinese people attach importance to moral cultivation, moral education, enrich the Chinese descendants should have the basic moral character. Until today, these ethical norms still have important practical significance, it is not only with the Marxist "on the comprehensive development of human" ideas are basically the same, but also with our current basic education policy. At the same time, the Chinese traditional culture also contains a unique way of moral cultivation and Confucianism emphasizes the inherent strength of the main body of moral cultivation, thereby enhancing the moral level of the main body. In the atmosphere of building a harmonious society, it is of great practical significance to strengthen the ideological and moral construction of college students and cultivate talents both ability and political integrity.

The Cultivation Function of Political Conservation. Chinese outstanding traditional culture to promote the country's patriotic spirit, such as $\mathrm{Gu}$ Yanwu's "rise and fall of the world, every man's responsibility," the patriotic feelings, "the country and forget the family, the public and forget the private" dedication, "the first worry and worry , After the world of music and music "

Of the noble character, embodies the country, society, friends and their own interests and solidarity. Whether it is Wen Tianxiang or Yue Fei and other heroes, their great achievements and profound influence and inspires generation after generation of the hearts and minds of the motherland, to play the important task of cultivating a high degree of political literacy. The ideological education in colleges and universities is a successor to cultivate a large number of politically qualified and thoughtful socialist undertakings for the country and cultivate the social responsibility of college students. The excellent traditional culture of China provides rich cultural resources for realizing this educational goal.

\section{The New Problems in Current Ideological Work of Colleges and Universities}

Colleges and universities have always been the gathering place and intersection of social and ideological trends at home and abroad, and do ideological work in colleges and universities not only the quality of personnel training in colleges and universities, but also the fate of the party and the long-term stability of the country. At present, with the political multipolarization and the process of economic globalization accelerating, social informatization and cultural diversification are increasing day by day, colleges and universities as the ideological frontier, facing more and more challenges.

The Continuous Infiltration of Western Ideology and It Has Effect on the College Teachers and Students' Socialist Ideology of Identity. With the process of globalization, Western developed countries on the penetration of ideology in our country to achieve the level of all-pervasive.

They through a variety of means, a variety of channels, a planned purpose for the younger generation of our country, will be beautifully packaged values, Western culture and other subtle influence on all aspects of social life, trying to shake the majority of teachers and students in this way to the country, National and traditional Chinese culture of identity, so that our ideological security and cultural security is facing a more complex situation. In real life, part of the intellectuals in colleges and universities out of context, blindly worship the West's freedom, democracy, human rights, and even irresponsible published inappropriate remarks, had a very serious negative impact. Therefore, colleges and universities to help teachers and students recognize the true colors of Western democracy, learn to use Marxist positions, views and methods to understand, analyze and solve problems.

The Struggle for Peaceful Evolution of the Internet Has Become Increasingly Prominent, and the Cohesion of Socialist Ideology Has Been Eroded. At present, with the vigorous rise of new media, the Internet also has the ideological function, the Western ideology system of discourse system through the network for people and positions. For a long time, the Western developed countries use BBS, forums and other network communication tools, the use of the Voice of America, 
Epoch Times, Beijing Spring, free news and other sites criticized and slandered our political system, the intention of China into the West "cultural colony" The According to the findings of the China Report Hall, one-third of our country is concentrated in the 20-29 year olds, accounting for one quarter of the netizen's career structure, and the "Guangming Daily" published on April 3, 2015 Of the survey shows that the current college students access to information channels are $93.7 \%$ through the network (mobile phone), so we can see that college students rely on the network is quite high. On the Internet, the Western values are influenced by the novel, micro-film, joke network derivative culture imperceptibly affect the life of college students in an attempt to make our contemporary college students become "defeated generation". College students lack the theoretical foundation and life experience, their ideological point of view and the value orientation is very susceptible to the so-called "historical truth" and "foreign comment". Therefore, the struggle for the peaceful evolution of the network has a negative impact on college students and ideological and political work in colleges and universities.

The Contradictions of Economic, Social Transformation Period Are Intensified, Affecting the Development of Students "Three Views". In the 21st century, with the economic transformation, the acceleration of social transition, reform and opening up the process of bringing the various contradictions and interests of the dispute is in the oscillation adjustment process. At the same time, the social values also show a diverse, diverse and changing situation, some decadent ideology and culture and even violate the social morality of information, pornographic violence and other content into the life of contemporary college students, "reading useless, reading poor" on the tune, "ant" and "dwelling" continue to appear, "the history of the most difficult season" report, to the students caused great ideological and psychological pressure. Students are still in the world outlook, outlook on life and values of the formation of these one-sided, false arguments weakened the cultivation of college students' values and ideals and beliefs education, misleading the correct understanding of the socialist ideology of college students, the impact of our college ideology Education work, as we must face the reality of the problem.

\section{The Promotion Role of Chinese Outstanding Traditional Culture on the Ideological Work of Colleges and Universities}

Chinese outstanding traditional culture is the spirit of the Chinese nation's soul, the Qing Dynasty scholar Gong Zizhen pointed out that "want to die their country, must first destroy its history, to destroy their families, must first destroy its culture", we can see inheritance and development of Chinese outstanding Traditional culture is the foundation of our firmness in the world of cultural agitation. Cultural heritage and innovation is one of the four basic functions of colleges and universities, and colleges and universities are also the main positions of ideological work. Therefore, colleges and universities should learn the essence of Chinese traditional culture in the same way. In the interaction with the times to promote the development of ideological work in colleges and universities, on the other hand, by consolidating the basic principles established by the mainstream ideology, reflecting the value of Chinese outstanding traditional culture.

Chinese Excellent Traditional Culture Has Enhanced the Guiding Position of Marxism in the Ideological Work of Colleges and Universities. General Secretary Xi Jinping stressed that to grasp the ideological work of colleges and universities and we must adhere to the guiding ideology of Marxism in the ideology of colleges and universities, through the Marxist world outlook and methodology, historical materialism and dialectical materialism, to strengthen the Marxist ideology to lead. So as to help college students distinguish between right and wrong, "good life first button."

Chinese excellent traditional culture and Marxism are closely blending, Marxism in the process of China, continue to produce new forms, the formation of the theoretical system of socialism with Chinese characteristics. First of all, Chinese outstanding traditional culture and Marxism meet each other, "Chinese philosophy in the materialist tradition, rich dialectical thinking, and Marxist dialectical materialism have a place of mutual fit" [3]. Mao Zedong Thought, Deng Xiaoping Theory, the important thinking of the 'Three Represents, the scientific concept of development and the concept of "harmonious society" are the fruits of Chinese traditional Chinese culture of 
Marxism in China. Second, the socialism with Chinese characteristics is rooted in the fertile soil of Chinese outstanding traditional culture, forming a unique cultural gene, has a profound historical origins and extensive practical basis [4]. Finally, Chinese excellent traditional culture provides a rich ideological resource for the education of socialist core values in colleges and universities. The university has embedded the contents of the socialist core values into the campus cultural activities through the development of classical reading and moral lectures.

Chinese Excellent Traditional Culture Provides Cultural Support for Ideological Work in Colleges and Universities. Colleges and universities need to continue to consolidate the mainstream ideology and this process is essentially the university to maintain the mainstream cultural values of the process. In the modern international competition, culture has become an important factor to improve the competitiveness of a nation. The excellent traditional culture of China shows the unique charm of Chinese culture and provides a theoretical basis for enhancing the soft power of culture. At the same time, their own social identity value of resources, to achieve the socialist ideology of cultural identity.

First, the excellent traditional culture of China promotes the construction of the ideal personality of contemporary college students, and enhances the beliefs and identities of college teachers and students to the ideal of communism. The cultivation of ideal personality is the focus of Chinese philosophy. The excellent traditional culture of China attaches great importance to human moral education, and fosters the pursuit of ideal personality and the pursuit of spiritual faith in daily life. In today's colleges and universities, some teachers and students over-pursuit of material and personal interests of the satisfaction, and ultimately lead to the loss of teachers and students of the school, the lack of ideals and beliefs and the emergence of historical nihilism. The ideal of communism is the ultimate goal of the development of human society. Therefore, we need to excavate the cultural resources of the ideal society in the traditional society, and pursue the value of "meritorious service", "virtue" and "speech" and convert it into the ideal of communism And the belief in socialism with Chinese characteristics.

Second, Chinese outstanding traditional culture to achieve the transformation and development of traditional moral culture, enhance the teachers and students of the socialist moral system of identity. Moral culture is an important spiritual force that affects the development of specific social economy, and it is also the key to enhance the cohesion of the Chinese nation. Colleges and universities are the highlands of social and moral culture, more obligation and responsibility to stick to the "moral fence", so that the social and moral culture of the Holy Land and spiritual home, thus affecting and lead the social and cultural development. Chinese fine traditional culture in the "filial piety for the German", "Heaven and Man" and "benevolence and loyalty and forgiveness" and other moral norms give the unique spirit of the Chinese nation to establish a rational moral thinking with cultural vitality for the modern society. China 's outstanding traditional culture for the strengthening of moral and cultural construction of colleges and universities to create a better social atmosphere, and promote the construction of teachers and teachers in colleges and universities, and guide students to establish national culture self - confidence and self - consciousness.

\section{Acknowledgements}

Fund Project: Hubei University Student Work Research Association 2016 - 2017 Annual Project " Research on new media promoting college students on the traditional Chinese culture inheritance and carry forward" (No. 1617YA10); Wuhan Textile University 2016 ideological and political education research project "The fine traditional Chinese culture into the ideological and political education of college students under the new media environment "(No. 163099). The achievement of "Studio of career planning and guidance for college students" instructor boutique project 2016 in WTU. 


\section{References}

[1] Decision of the Central Committee of the Communist Party of China on Deepening the Reform of Cultural System and Promoting the Great Development and Prosperity of Socialist Culture [N]. People's Daily, 2011-10-26

[2] Zhang Weiyi. Adhere to the Marxist guiding position to do ideological work in colleges and universities [J]. China Higher Education, 2015, (23)

[3] Zhang Dainian. Zhang Dainian Complete Works: Volume 7 [M]. Shijiazhuang: Hebei People's Publishing House, 1996: 159.

[4] Xi Jinping on governance country governance [M]. Beijing: Foreign Language Press, 2014: 156,164 